\title{
STANDAR PERENCANAAN KEPERAWATAN
}

\author{
Audina Tio Junianti Manik
}

audina.junianti@gmail.com

\section{Latar Belakang}

Memberikan pelayanan asuhan keperawatan haruslah dilakukan dengan professional. Menurut Kusnanto (2004) pelayan keperawatan profesional (professional nursing service) adalah rangkaian upaya melaksanakan sistem pemberian pelayanan asuhan keperawatan kepada masyarakat sesuai dengan kaidahkaidah keperawatan sebagai profesi.

Asuhan keperawatan adalah suatu pendekatan untuk pemecahan masalah yang memampukan perawat untuk mengatur dan memberikan asuhan keperawatan. Standar asuhan yang tercantum dalam Standar Praktik Klinis Keperawatan terdiri dari lima fase asuhan keperawatan: 1) Pengkajian; 2) Diagnosa; 3 ) Perencanaan; 4) Implementasi; dan 5) Evaluasi. Salah satu manfaat dari penerapan asuhan keperawatan yang baik adalah meningkatkan mutu dan kualitas pelayanan dalam bidang keperawatan (Kozier, 2010).

Perawat sebagai suatu profesi dapat mempertahankan dan meningkatkan mutu asuhan keperawatan maka jawabannya adalah dengan adanya standar. Standar merupakan level kinerja yang diinginkan dan yang dapat dicapai dimana kerja aktual dapat dibandingkan (Nursalam, 2011). Menurut Sumijatun (2010, p.88) permasalahan pelayanan keperawatan di negara Indonesia adalah banyaknya perawat yang belum melakukan asuhan keperawatan sesuai dengan standar. Di sebagian besar tatanan pelayanan keperawatan, masih terbatas melakukan kegiatan-kegiatan yang belum memenuhi kaedah asuhan keperawatan secara profesional yang bertanggung gugat.

Perencanaan asuhan keperawatan bersifat individualistic dan responsive terhadap kebutuhan dasar pasien. Perencanaan ini bertujuan agar menyusun strategi apa yang akan dilakukan perawat untuk mengatasi hambatan atau masalah pasien. Tujuan penulisan ini adalah untuk memberikan gambaran mengenai 
perencanaan asuhan keperawatan yang ada di sebagian rumah sakit di Indonesia.

\section{Metode}

Penulisan ini penulis buat dengan model literature riview dengan membaca dan menganalisis serta membandingkan beberapa berbagai sumber online dengan rentang batasan waktu 2012 sampai tahun 2020. Dalam pencarian, penulis mendapatkan dua modul bahan ajar cetak dan delapan jurnal online yang sesuai dengan topik.

Dan juga penulis mengambil dua jurnal yang membahas tentang perencanaan keperawatan yang ada di rumah sakit yang berbeda.

Jurnal pertama yang penulis ambil berjudul "Hubungan Penerapan Metode Tim dengan Rencana Asuhan Keperawatan Pasien di Ruang Rawat Inap” oleh Sari Madonni, Erwin dan Rismadefi Woferst. Penelitian ini merupakan penelitian kuantitatif dengan menggunakan desain penelitian deskriptif korelasi dengan pendekatan cross sectional. Metode pengumpul data menggunakan alat pengumpulan data berupa kuisoner dan lembar observasi yang dibuat oleh peneliti berdasarkan konsep dan tinjauan pustaka. Selanjutnya, peneliti melakukan observasi pada 3 rekam medik pasien tim berdasarkan lembar observasi.

Jurnal kedua yang penulis ambil berjudul "Analisis Ketidaksinambungan Dokumentasi Perencanaan Asuhan Keperawatan : Metode Ishikawa" oleh Purnama Christina, Agustin Indracahyani, Aat Yatnikasaria. Metode yang digunakan adalah metode analisis gap yaitu membandingkan antara kondisi pelayanan keperawatan di rumah sakit khusus ibu dan anak Jakarta dengan kondisi ideal sesuai referensi. Analisis dalam studi kasus inimenggunakan pendekatan fungsi manajemen keperawatan dan metode Ishikawa untuk mencari akar masalah.

\section{Hasil}

Dari jurnal pertama yang berjudul "Hubungan Penerapan Metode Tim dengan Rencana Asuhan Keperawatan Pasien di Ruang Rawat Inap” oleh Sari Madonni, Erwin dan Rismadefi Woferst, berdasarkan table 3 nya diketahui bahwa tim yang memiliki rencana asuhan keperawatan yang kurang lengkap lebih banyak ditemukan oleh peneliti yaitu sebanyak $16(51,6 \%)$ rencana asuhan keperawatan. Tabel 4 terdapat hubungan yang signifikan antara penerapan metode tim dengan rencana asuhan keperawatan pasien di ruang rawat 
inap. Hasil analisis hubungan metode tim dengan rencana asuhan keperawatan pasien di ruang rawat inap diperoleh bahwa penerapan metode tim yang baik memiliki rencana asuhan keperawatan yang lengkap yaitu 12 rekam medik $(38,4 \%)$ lebih banyak dibandingkan tim yang menerapakan metode tim yang kurang, dimana hanya terdapat 3 $(9,7 \%)$ rencana asuhan keperawatan saja.

Dari jurnal kedua yang berjudul "Analisis Ketidaksinambungan Dokumentasi Perencanaan Asuhan Keperawatan : Metode Ishikawa" oleh Purnama Christina, Agustin Indracahyani, Aat Yatnikasaria, diperoleh hasil bahwa Perawat primer merencanakan asuhan keperawatan berdasarkan analisis data dan Panduan Asuhan Keperawatan (PAK) yang berlaku di rumah sakit pada lembar POC. POC diimplementasikan oleh perawat pelaksana yang kemudian didokumentasikan dalam flowsheet pasien. Hasil observasi ditemukan rencana asuhan keperawatan pada lembar POC belum sesuai denganflowsheetharian pasien, contohnya di POC terdapat hanya 5 masalah asuhan keperawatan, namun padaflowsheetharian dapat ditemukan 10 sampai 12 masalah keperawatan. Perencanaan Bidang Keperawatan terkait metode penugasan asuhan keperawatan sudah berjalan sangat baik. Hal ini dibuktikan dengan adanya regulasi Metode Asuhan Keperawatan Primer (MAKP), Panduan MAKP dan Panduan Asuhan Keperawatan (PAK) yang berlaku di Rumah Sakit.

\section{Pembahasan}

Disini penulis akan lebih membahas mengenai perencanaan keperawatan. Perencanaan merupakan suatu langkah sitematis untuk mengatasi masalah keperawatan sesuai dengan tujuan yang diharapkan. Jika diagnosa berubah maka intervensi harus mengikuti diagnosa yang muncul dan terdokumentasi.

Perencanaan keperawatan merupakan tahap pada proses keperawatan yang dilakukan setelah penegakan Diagnosa Keperawatan Perencanaan keperawatan adalah suatu rangkaian kegiatan penentuan langkahlangkah pemecahan masalah dan prioritasnya, perumusan tujuan, rencana tindakan dan penilaian asuhan keperawatan pda pasien/klien berdasarkan analisis data dan diagnosa keperawatan. Perencanaan adalah pengembangan strategi desain untuk mencegah, mengurangi, dan mengatasi masalahmasalah yang telah diidentifikasi dalam diagnosis keperawatan. Desain perencanaan menggambarkan sejauh mana Anda mampu menetapkan cara menyelesaikan masalah dengan efektif dan 
efisien. Adapun tujuan perencanaan keperawatan itu dibuat yaitu tujuan administrasi (Administrasi mengidentifikasi fokus keperawatan, fokus intervensi keperawatan dapat diidentifikasi melalui rencana keperawatan yang disusun. Secara administrasi menyediakan kriteria guna mengevaluasi hasil keperawatan. Kriteria hasil merupakan indikator pencapaian tujuan yang telah Anda tetapkan dan indikator/batasan bagaimana tujuan itu akan dicapai sehingga gambaran kriteria keberhasilan dari diagnosis keperawatan yang diangkat sudah ditetapkan terlebih dahulu), dah tujuan klinik (Merupakan penunjuk dalam pelaksanaan tindakan keperawatan, dimana tindakan keperawatan selalu berpedoman pada perencanaan yang telah Anda buat. Tidak ada satu tindakan pun yang keluar dari perencaan, semua rencana yang Anda tetapkan merupakan pilihan yang rasional/ilmiah dan betul-betul diperlukan untuk mengatasi masalah yang terjadi.).

Dalam membuat rencana keperawatan, ada beberapa langkah yang dilakukan:

a. Menentukan Prioritas Masalah.

Prioritas masalah merupakan upaya perawat untuk mengidentifikasi respons klien terhadap masalah kesehatannya, baik aktual maupun potensial. Untuk menetapkan prioritas masalah seringkali digunakan hierarki kebutuhan dasar manusia. Pada kenyataannya perawat tidak mampu menyelesaikan permasalahan klien secara bersamaan, oleh karena itu diperlukan upaya untuk memprioritaskan masalah. Prioritas diagnosa dibedakan dengan diagnosa yang penting sebagai berikut:

a) Prioritas diagnosa merupakan diagnosa keperawatan, jika tidak diatasi saat ini akan berdampak buruk terhadap kondisi status fungsi kesehatan klien.

b) Diagnosa penting adalah diagnosa atau masalah kolaboratif dimana intervensi dapat di tunda tanpa mempengaruhi status fungsi kesehatan klien.

\section{b. Menentukan Tujuan dan Kriteria Hasil.}

Membuat tujuan berarti membuat standar atau ukuran yang digunakan untuk melakukan evaluasi terhadap perkembangan klien dan keterampilan dalam merawat klien. Tujuan keperawatan yang baik adalah pernyataan yang menjelaskan suatu tindakan yang dapat diukur berdasarkan kemampuan dan kewenangan perawat. Karena kriteria hasil diagnosa keperawatan mewakili status kesehatan klien yang dapat dicapai atau di 
pertahankan melalui rencana tindakan keperawatan yang mandiri, sehingga dapat membedakan antara diagnosa keperawatan dan masalah kolaboratif. Hasil dari diagnosa keperawatan tidak dapat membantu mengevaluasi efektivitas intervensi keperawatan jika tindakan medis juga diperlukan.

a) Tujuan Perawatan berdasarkan SMART yaitu:

1) $S$ : Spesific (tidak memberikan makna ganda).

2) $\mathrm{M}$ : Measurable (dapat diukur, dilihat, didengar, diraba, dirasakan ataupun dibantu).

3) A : Achievable (secara realistis dapat dicapai).

4) $R$ : Reasonable (dapat dipertanggung jawabkan secara ilmiah).

5) $\mathrm{T}$ : Time (punya batasan waktu yang sesuai dengan kondisi klien). Contoh: Setelah dilakukan asuhan keperawatan selama 1 x 24 jam, masalah gangguan rasa nyaman: nyeri dapat terasi.

b) Kriteria Hasil Kriteria hasil merupakan standar yang harus dicapai manakala perawat memberikan asuhan keperawatan. Kriteria ini dipakai sebagai dasar untuk memberikan pertimbangan terhadap rencana tindakan yang akan diberikan kepada klien.

\section{c. Menentukan Rencana Tindakan.}

Rencana tindakan yang akan diberikan pada pasien ditulis secara spesifik, jelas dan dapat di ukur. Rencana perawatan dibuat selaras dengan rencana medis, sehingga saling melengkapi dalam meningkatkan status kesehatan pasien. Dalam merumuskan rencana tindakan yang perlu diperhatikan adalah:

a) Rencana tindakan keperawatan merupakan desain spesifik intervensi yang membantu klien mencapai kriteria hasil

b) Dokumentasi rencana tindakan yang telah diimplementasikan harus ditulis dalam sebuah format agar dapat membantu perawat untuk memproses informasi yang didapatkan selama tahap pengkaian dan diagnosa keperawatan

c) Perencanaan bersifat indivisual sesuai dengan kondisi dan kebutuhan klien

d) Bekerjasama dengan klien dalam merencanakan intervensi

d. Dokumentasi. 
Tipe Rencana Tindakan

Keperawatan terdiri dari:

1) Diagnostik/Obserevasi

Rencana tindakan keperawatan diagnostik adalah rencana tindakan untuk mengkaji atau melakukan observasi terhadap kemajuan klien dengan pemantauan secara langsung yang Anda lakukan secara kontinu. Dengan observasi ini, diharapkan hal-hal yang Anda tetapkan dalam kriteria hasil dapat Anda pantau secara berkesinambungan sampai tujuan berhasil dicapai.

2) Terapeutik/Nursing Treatment Rencana tindakan keperawatan terpeutik adalah rencana tindakan yang ditetapkan untuk mengurangi, memperbaikidan mencegah perluasan masalah.Rencana tindakan ini berupa intervensi mandiri Anda yang bersumber dari ilmu, kiat dan seni keperawatan. Dalam suatu masalah keperawatan, biasa didapatkan beberapa (lebih dari satu) alternatif penyelesaian masalahnya, Anda dituntut untuk dapat memilih mana yang paling sesuai untuk Anda tetapkan pada pasien.

3) Penyuluhan /Health Education/Pendidikan Kesehatan
Rencana tindakan keperawatan yang berbentuk pendidikan kesehatan adalah rencana tindakan yang Anda tetapkan bertujuan untuk meningkatkan perawatan diri kilen dengan penekanan pada partisispasi klien untuk betanggung jawab terhadap perawatan diri, terutama untuk perawatan dirumah. Penyuluhan atau pendidikan kesehatan diperlukan, terutama bila masalah keperawatan dan kriteria hasil berhubungan dengan aspek kognitif, afektif, dan psikomotor. Penyuluhan yang Anda lakukan dapat berbentuk penyuluhan umum tentang segala sesuatu tentang penyakit dan perawatan klien atau juga lebih spesifik sesuai dengan masalah yang terjadi.

4) Rujukan atau Kolaborasi atau Medical Treatment

Rencana tindakan keperawatan kolaboratif adalah tindakan medis yang dilimpahkan kepadaAnda. Rencana kolaboratif ini disesuaikan dengan masalah yang terjadi. Masalah yang bersifat kognitif, afektifdan psikomotor mungkin tidak memerlukan tindakan medis. 


\section{Penutup}

Perencanaan keperawatan adalah suatu rangkaian kegiatan penentuan langkahlangkah pemecahan masalah dan prioritasnya, perumusan tujuan, rencana tindakan dan penilaian asuhan keperawatan pda pasien/klien berdasarkan analisis data dan diagnosa keperawatan. Perencanaan keperawatan atau bisa juga disebut intervensi meliputi tindakan mengidentifikasi skala prioritas perencanaan, membuat kerangka acuan untuk identifikasi kegiatan yang bila dilakukan klien secara mandiri. Langkah-langkah dalam membuat perencanaan keperawatan adalah menentukan prioritas masalah, menentukan tujuan dan tindakan hasil, menetukan rencana tindakan, dan pendokumentasian. Jadi, kita sebagai calon perawat professional, kita harus menekuni dari setiap tindakan yang akan kita lakukan, agar dapat meningkatkan kualitas kita sebagai perawat. Demikian penulisan yang bisa saya buat, semoga bermanfaat bagi pemcaba.

Terimakasih.

\section{Daftar Pustaka}

Agustin, R. R., Koeryaman, M. T., Amira, I. (2020). Gambaran Tingkat Cemas, Mobilisasi, dan Nyeri Pada Ibu Post Operasi Sectio Sesarea di RSUD dr. Slamet Garut.
Jurnal Kesehatan Bakti Tunas Husada:

Jurnal Ilmu Ilmu Keperawatan, Analis

Kesehatan dan Farmasi, 20(2), 223-234.

(https://mail.ejurnal.stikes-

bth.ac.id/index.php/P3M_JKBTH/article/vie w/613/516)

Budiono.(2016).Modul Bahan Ajar Cetak

Keperawatan 'Konsep Dasar

Keperawatan'.Jakarta: Pusdik SDM

Kesehatan Badan Pengembangan dan

Pemberdayaan Sumber Daya Manusia

Kesehatan.

(http://bppsdmk.kemkes.go.id/pusdiksdmk/ wp-content/uploads/2017/08/Konsep-dasarkeperawatan-Komprehensif.pdf?opwvc=1)

Butar-Butar, J., \& Simamora, R. H. (2016). Hubungan Mutu Pelayanan Keperawatan dengan Tingkat Kepuasan Pasien Rawat Inap di RSUD Pandan Kabupaten Tapanuli Tengah. Jurnal Ners Indonesia, 6(1), 50-63.

Christina, P., Indracahyani, A., Yatnikasaria, A. (2019). Analisis Ketidaksinambungan Dokumentasi Perencanaan Asuhan Keperawatan : Metode Ishikawa. Jurnal Ilmiah Kesehatan, 12(2), 518524. (https://journal.stikesmuhpkj.ac.id/index.php/jik/article/view/166/112) 
Koerniawan, D., Daeli, N. E., Srimiyati, S.

(2020). Aplikasi Standar Proses

Keperawatan : Diagnosis, Outcome, dan

Intervensi pada Asuhan Keperawatan.

Jurnal Keperawatan Silampari, 3(2), 739-

751.

(https://journal.ipm2kpe.or.id/index.php/JKS $\underline{\text { /article/view/1198) }}$

Madonni, S., Erwin, Woferst, R. (2015).

Hubungan Penerapan Metode Tim dengan

Rencana Asuhan Keperawatan Pasien

Diruang Rawat Inap. JOM, 2(2).

(https://media.neliti.com/media/publications/ 185493-ID-hubungan-penerapan-metodetim-dengan-ren.pdf)

Olfah, Y., Ghofur A. (2016). Modul Bahan Ajar Cetak Kebidanan 'Dokumentasi Keperawatan'. Jakarta : Pusdik SDM Kesehatan Badan Pengembangan dan Pemberdayaan Sumber Daya Manusia Kesehatan.

(http://bppsdmk.kemkes.go.id/pusdiksdmk/ wp-content/uploads/2017/08/Dokumentasi-

Keperawatan.pdf)

Rahayu, C. D., Mulyani, S. (2020).

Pengambilan Keputusan Klinis Perawat.

Jurnal Ilmiah Kesehatan, 1-11.

(https://ojs.unsiq.ac.id/index.php/jik/article/d ownload/1332/780)
Simamora, R. H. (2005). Hubungan

Persepsi Perawat Pelaksana Terhadap Penerapan Fungsi Pengorganisasian Yang

Dilakukan Oleh Kepala Ruangan Dengan Kinerjanya Diruang Rawat Inap RSUD Koja Jakarta Utara (Doctoral dissertation, Tesis FIK UI, Tidak dipublikasikan).

Supratti, Ashriady. (2016).

Pendokumentasian Standar Asuhan

Keperawatan di Rumah Sakit Umum Daerah Mamuju, Indonesia. Jurnal Kesehatan MANARANG, 2(1), 44-51. (http://jurnal.poltekkesmamuju.ac.id/index.p hp/m/article/download/13/12)

Wirdah, H., Yusuf, M. (2016). Penerapan Asuhan Keperawatan oleh Perawat Pelaksana di Rumah Sakit Banda Aceh. Jurnal Ilmiah Mahasiswa, 1(1), (http://www.jim.unsyiah.ac.id/FKep/article/ view/1491/1799)

Yulianti, F. M. (2017). Asuhan Keperawatan pada Balita yang Mengalami Diare dengan Dehidrasi Sedang di Rumah Sakit Umum dr. Wahidin Sudiro Husodo Mojokerto. Hospital Majapahit, 9(1), 70-78. (http://ejournal.stikesmajapahit.ac.id/index.p $\underline{\mathrm{hp} / \mathrm{HM} / \text { article/view/141) }}$ 
